\title{
“THE ORIGINAL EYE": WHITMAN, SCHELLING AND THE RETURN TO ORIGINS
}

ROBERT J. SCHOLNICK

IN 1855 WaLT Whitman's Leaves of Grass impressed its first readers, as it continues to impress new readers, with its startling originality. Presenting himself as one whose artistic power derives from his ability to stand independent of all literary traditions, the speaker of "Song of Myself" promises the reader a similar liberation: "You shall no longer take things at second or third hand . . . nor look through the eyes of the dead ... nor feed on the spectres of books." The "yawp" of this poet, "one of the roughs," is "barbaric," a point that Whitman emphasized by including a portrait of himself as an open-shirted workman on the frontispiece. ${ }^{1}$ As he explained in his own unsigned review of Leaves of Grass for the Brooklyn Daily Times on September 29, 1855, "The effects he produces in his poems are no effects of artists or the arts, but the effects of the original eye or arm, or the actual atmosphere, or tree, or bird. You may feel the unconscious teaching of a fine brute, but will never feel the artificial teaching of a fine writer or speaker."2 Of this he succeeded in convincing even the reviewer for the North American Review, Edward Everett Hale, who in January 1856 praised Whitman precisely for his success in overcoming all conventions, including the familiar convention of overcoming conventions: "He has a horror of conventional language of any kind. . . . Now a great many men have said this before. But generally it is the introduction to something more artistic than ever,-more conventional and strained. . . . In this book, however, the prophecy is fairly unfulfilled in the accomplishment."3

"Insist on yourself; never imitate," Emerson had written in "SelfReliance," identifying independence and uniqueness as essential components of the American character and reinforcing a Romantic imperative. Emerson warned that "Your own gift can present every moment with the cumulative force of a whole life's cultivation; but of the adopted talent of another, you have only an extemporaneous, half possession ..... Every great man is a unique." "Yet, as Thomas McFarland has observed, Emerson also wisely recognized that the artist confronts a basic contradiction about this newly enshrined value of originality: "Along with his insistence on originality, the author of Self-Reliance paradoxically conceded the full claims of tradition: 'The 
truth is all works of literature are Janus faced and look to the future and the past. Shakespeare, Pope, and Dryden borrow from Chaucer and shine by his borrowed light. ... There never was an original writer. Each is a link in an endless chain. To receive and to impart are the talents of the poet and he ought to possess both in equal degrees. . . . Every great man, as Homer, Milton, Bacon, and Aristotle, necessarily takes up into himself all the wisdom that is current in his time." "In the late "Quotation and Originality," Emerson proclaims the near disappearance of the author: "The originals are not original. There is imitation, model and suggestion, to the very archangels, if we knew their history. The first book tyrannizes over the second. Read Tasso, and you think of Virgil; read Virgil, and you think of Homer; and Milton forces you to recognize how narrow are the limits of human invention. The Paradise Lost had never existed but for these precursors." 6 That Whitman went out of his way to disclaim participation in the "artificial teaching" of "fine" writing, choosing instead to present himself as an untutored "brute," suggests that he was well aware of the complex, paradoxical, even insoluble problem of originality at this "late" stage of literary history. He promised in the 1855 preface that "I will not have in my writing any elegance or effect of originality to hang in any way between me and the rest like curtains" (14). "Originality" had come to imply literary tricks, and Whitman would have none of it.

I will argue that Whitman's presentation of himself as an original poet in Leaves of Grass was based on an aesthetic strategy involving an imaginative act of return to origins, to discover a creative space from which he could "speak at every hazard, / Nature without check with original energy," to use a phrase that in 1881 he added to the first section of "Song of Myself." In imaginatively re-creating a time and place of beginning, a place where, as in the second section, poet and reader can "possess the origin of all poems," he claims to have found an authentic and original voice (30). In turn, the poet's ability to recover origins-cosmic, national, personal, poetic-makes it possible for him in "Song of Myself" to realize his large vision, to fashion a new creation story, a new myth, for the new age. Still, reflecting the ambiguity of the concept of originality, this strategy was not original with Whitman but was a well-established part of the Romantic aesthetic tradition in Germany, England, and America. To cite one notable example, Frederich Schelling, addressing the problem of achieving an original voice at an "advanced" stage in artistic history in On the Relation of the Fine Arts to Nature (1807), an essay included by Frederic Henry Hedge in Prose Writers of Germany, published in Philadelphia in 1847, formulates an aesthetic philosophy that prefigures essential aspects of Whitman's practice in "Song of Myself." Schelling recommends that the artist "con- 
stantly return" to the "first rudiments" of art so as to "create . . . with free original energy." Significantly, Schelling called upon the artist to respond as well to the revolutionary moment, to "the new world ... [which] loudly demands higher standards and an entire renovation."7

In the famous 1855 letter greeting Whitman "at the beginning of a great career" and thanking him for the gift of Leaves of Grass, "the most extraordinary piece of wit and wisdom that America has yet contributed," Emerson recognized that this poetry "must have had a long foreground somewhere for such a start." 8 Whitman was successful in Leaves of Grass in hiding the markers of that indebtedness, to Emerson himself as well as to other precursors. The return to origins enabled Whitman to discover at once an "original" voice and his large subject matter: a new creation story that incorporates the astounding revelations of the latest scientific discoveries as well as the large spirit of American democracy. Paradoxically, this most American of poets conducted his revolution in ways authorized more than fifty years earlier by his Romantic forebears, particularly Schelling. For Whitman, as Leslie Brisman has written of Schelling and Coleridge, "the imagination is both in search of the origin of things, where natural and literary things come from, and in search of the nature of originality, what it means to take the self as a source."9

In the 1881 edition Whitman added a phrase, "and sing myself," to the first line of "Song of Myself," clearly signifying his awareness that he was participating in the epic tradition. The concluding stanza that he added to the first section makes explicit what had long been implicit: that much as he had been formed by the tradition, he had also found a way to move outside it: "Creeds and schools in abeyance, / Retiring back awhile sufficed at what they are, but never forgotten. . . ." The poet who would send his "barbaric yawp over the rooftops of the world" acknowledges the shaping power of an intellectual heritage that "never" can be "forgotten." Yet, he recognizes that if he is to speak as a poet, he must discover, if not a total escape from the tradition, at least a way to hold it "in abeyance." Only then will he be able to proceed to his essential purpose: "I harbor for good or bad, I permit to speak at every hazard, / Nature without check with original energy" (29). Now he can claim that the power of his originating speech derives not from literary tradition, or even immediately from himself, but from the "original energy" of nature, conceived as an undefiled creative power present at the beginning of the cosmos and responsible for its continuing evolution. 
Paradoxically, Whitman's discovery of an original voice through this return proceeds by reference to its polar opposite, "creeds and schools." His awareness of the complexities of the modern literary situation defines the terms of his move to recover the "original energy" of nature. A further paradox is that now the poet does not claim to be speaking as an individual, but through something larger, nature itself. Opposed to "creeds and schools" is not the unique self, but "original energy," which he presents as the force that drives at once the self and the external world, a presence that will speak through him. Writing in Section 17 that "These are really the thoughts of all men in all ages and lands, they are not original with me," Whitman disclaims originality in favor of universality (45).

The paradoxical quality of originality is reflected in the words themselves. The original is the underived, that which, not copied or imitated, is new; we think of the original in art as coming essentially from the imaginative power of the artist. "Original," however, derives from "origins," which calls attention to parentage, ancestry, and derivation, and points to the source of everything in something anterior. As reflected in the extraordinary public interest during the 1840 s and ' 50 s in a biology devoted to understanding the origin of the species, an astronomy which, through the nebular hypothesis of Laplace, investigated the origins of the cosmos, and a geology that sought to explain the long development of the earth itself, the mid-nineteenth century imagination in America was fascinated with the notion of origins, beginnings and sources. At the same time, with the increasingly rapid pace of change, the culture seemed to be moving into a future that had no analogue, that appeared to be self-derived and original, and that represented history as a linear progress. While as a journalist Whitman celebrates the progressive movement of the American society, and as poet he expresses a radical democratic vision, his poetry is also written out of a sense in which human life is governed by patterns of return and regeneration, what Mircea Eliade has termed The Myth of Eternal Return. In this sense, Whitman's return to origins represents a "resistance," as Eliade has explained the underlying motive of return, "to history, a revolt against historical time, an attempt to restore this historical time, freighted as it is with human experience, to a place in the time that is cosmic, cyclical, and infinite."10 Further, this was a time when Christian myth had lost its traditional power or authority within the culture. In Myth and Literature in the American Renaissance, Robert D. Richardson, Jr. has explored the complex interrogation and reformulation by contemporary writers of the competing traditions of myth. ${ }^{11}$ These writers took it upon themselves to fashion a new concept of myth, which of course is centrally concerned with origins. Other writers in what F.O. Matthiessen has called The American Renaissance, or rebirth, 
shared this interest in exploring origins, in returning imaginatively to the creation of the cosmos to find there both an original voice and a source of the generative energy for their art, even while they faced the complex problems of a new American industrial order. ${ }^{12}$ In "The Poet" Emerson develops a theory of poetic language that returns the writer to a "time" even before the beginning of time, to capture there the "primal" power: "For poetry was all written before time was, and whenever we are so finely organized that we can penetrate into that region where the air is music, we hear those primal warblings, and attempt to write them down, but we lose ever and anon a word, or a verse, and substitute something of our own, and thus miswrite the poem. . . . Words and deeds are quite indifferent modes of the divine energy. Words are also actions, and actions are a kind of words." 13 To be a poet is to be first a reader of the original divine text, but given human fallibility, this reading is bound to be only partially successful, a misreading, what Harold Bloom termed a "misprision."14

Still, the return to origins remained a primary theme in Emerson, whose central question in Nature is "Why should not we also enjoy an original relation to the universe?" 15 In "Self-Reliance" he spoke of originality as a precondition for democracy: "When private men shall act with original views, the lustre will be transferred from the actions of kings to those of gentlemen," and he described the return to origins as the basis of spirituality. The ultimate fact behind all "original action" is "that source, at once the essence of genius, of virtue, and of life, which we call Spontaneity or Instinct. We denote this primary wisdom as Intuition, whilst all later teachings are tuitions. In that deep force, the last fact behind which analysis cannot go, all things find their common origin." In the return to the "common origin" of "all things," Emerson wrote, "the sense of being which in calm hours rises, we know not how, in the soul, is not diverse from things, from space, from light, from time, from man, but one with them, and proceeds obviously from the same source whence their life and being also proceed. We first share the life by which things exist and afterwards see them as appearances in nature and forget that we have shared their cause."16

In the "Spring" chapter of Walden, Thoreau reports that in witnessing the thawing of the bank at the pond "I am affected as if in a peculiar sense I stood in the laboratory of the Artist who made the world and me,-had come to where he was still at work, sporting on this bank, and with excess energy strewing his fresh designs about."17 The distance between past and present, Creator and created, disappears; the creation is an on-going process in which the human artist, Thoreau, participates with the divine Artist, forming with "excess energy" the "fresh designs" of his artistic universe, Walden. Despite the acknowledged potential of misreading the "primal warblings," Thoreau and 
Whitman, following Emerson, an originating figure for both, accept as a continuing directive the artist's imaginative return to the origins of time to capture for their art the originating energy of the creation.

Similarly, Poe described his purpose in Eureka as "to speak of the Physical, Metaphysical and Mathematical-of the Material, and Spiritual Universe:-of its Essence, its Origin, its Creation, its Present Condition and its Destiny." And he explained that the "general proposition" of the work "is this:-In the Original Unity of the First Thing lies the Secondary Cause of All Things, with the Germ of their Inevitable Annihilation." 18 In naming the "original unity of all things," did Poe have in mind something akin to a "big bang" theory? Far more than Emerson, Thoreau, and Whitman, Poe's vision of beginnings is balanced by a sense of an "inevitable annihilation."

Inseparable from the fascination of these writers with beginnings were their speculations on the origins of thought itself. As Leon Chai has explained, Poe came to understand that "the origin of the universe is really the origin of its idea, which Poe traces to the origin of thought itself." He termed this an idea which is "irrelative altogether-which not only presents to the understanding no obviousness of relation, either greater or less, to be considered, but subjects the intellect, not in the slightest degree, to the necessity of even looking at any relation at all." Chai asserts that these speculations on "irrelative thought" serve to "connect Poe with Romantic philosophical speculation. Almost half a century earlier, the necessity of an unmediated beginning in philosophy had impressed itself upon Fichte, Schelling, and Hegel with almost equal force. ... This beginning (in Fichte the principle $\mathrm{A}=\mathrm{A}$ or its corollary, self-consciousness; in Schelling the identity of subject and object; in the later Hegel, pure being) must justify itself on purely theoretical grounds: one begins with what is absolutely immediate, that whose existence does not depend on its relation to anything else, since that alone can form an absolute beginning." 19 At the heart of Schelling's Naturphilosophie is an aesthetic theory, the "notion of an absolute reason or identity which transcends the duality of subject and object altogether" and which "appears as a kind of unconscious force at work in the conscious subject ... and what most supremely incarnates this absolute identity, prior to all subject object division, is art itself." 20 Especially in the work of Schelling, this philosophical interest in origins finds expression in a theory of art directed at encouraging original creation. On the Relation of the Plastic Arts to Nature insists that through the artist, the "inspired seeker alone," humankind can understand its origins and continuing participation in "the holy, ever-creative original energy of the world, which generates and busily evolves all things out of itself" (510). The artist accomplishes this by "show[ing] to us, as in outline, this unadulterated energy of creation and activity in Nature" 
(512). When in the 1881 edition Whitman made explicit the intention of "Song of Myself" to "permit to speak at every hazard, / Nature without check with original energy" (p. 29), he echoes Schelling.

A lecture delivered in 1807, On the Relation of the Plastic Arts to Nature, is a central statement of the Romantic aesthetic. Along with Schelling's Philosophy of Art, it served as a major source for Coleridge, in Biographia Literaria, "On Poesy or Art," and elsewhere. In fact, so directly does Coleridge draw from Schelling that, as Thomas McFarland has written, he has been accused of plagiarizing from him. And yet, McFarland adds, "Karoline Herder confided to a correspondent that Schelling plagiarized from Johann Wilhelm Ritter (who himself suggested as much). 'In addition he thinks nothing of literary theft, and gives out as his own invention what others have told and entrusted to him. ... Results that Ritter has discovered and entrusted him with Schelling has presented as his own, but of course in quite a perverted way." "21 In considering the way that Schelling, in writing about originality, borrowed from other writers and how Coleridge took directly from Schelling, one wonders if the very profession of originality carries with it an implicit confession of its opposite.

In any event, both directly, most likely in a translation of major portions of the work by the Transcendentalist James Elliot Cabot published in Hedge's Prose Writers of Germany (1847) and through such sources as Coleridge's Biographia Literaria, which Whitman reviewed in the Brooklyn Eagle, ideas from this essay and other works by Schelling entered the Romantic mainstream and were readily available in America. ${ }^{22}$ For example, and to mention another meaning of original knowing, we might recall Matthiessen's remark that "Coleridge had stressed what was to be one of Emerson's recurrent themes, 'The all in each of human nature,'-how a single man contains within himself, through his intuition, the whole range of his experience. Coleridge, in turn, had quoted from Schelling: 'On the IMMEDIATE which dwells in every man, and on the original intuition, or absolute affirmation of it . . . all the certainty of knowledge depends.' Such a doctrine of knowledge lay behind the main developments of romantic literature, and naturally made a particular appeal to isolated, provincial America."23

By the mid-1840s, central ideas from the Romantic movement, Lawrence Buell has written, were made available "through the impact of such cultural middlemen as Coleridge, Carlyle, and Emerson upon the next generation of American writers, particularly Thoreau, Whitman, Melville, and Emily Dickinson."24 However, through Prose Writers of Germany in 1847 and other translations from the Germans, younger writers such as Whitman could by-pass the intermediaries and enjoy a more direct relationship to the German sources of Romanticism. In October 1847 the North American Review welcomed Hedge's anthol- 
ogy, asserting that "There is no book accessible to the English or American reader which can furnish so comprehensive and symmetrical a view to the uninitiated; and those already conversant with some of the German classics will find here valuable and edifying extracts from works to which very few in this country can gain access. ${ }^{25}$

In London in 1845, John Chapman, who became Emerson's English publisher, released a translation of the full work by A. Johnson under the title The Philosophy of Art: an Oration on the Relation between the Plastic Arts and Nature, but I have not discovered how widely this may have circulated in America. ${ }^{26}$ Only two years later Prose Writers of Germany appeared, with subsequent editions in 1849, 1852, and 1870. Hedge included excerpts from the beginnings of German prose in Luther and Boehme through Kant, Lessing, Lavater, Herder, Goethe, Schiller, Fichte, the Schlegels, to Hegel, Tieck, and Hoffmann. Several scholars have explored the importance for Whitman of this volume. In "Hedge's Prose Writers of Germany as a Source of Whitman's Knowledge of German Philosophy," Sister Mary Eleanor has identified ideas in both his prose and poetry that echo passages from a number of authors included by Hedge, and concludes that "one is tempted to suggest that this cumbersome, closely-printed volume had a real part in the shaping of Leaves of Grass."27 Floyd Stovall, reporting that at the time of his death Whitman owned a copy of Hedge, goes even further, remarking that "in making my own comparison, I have found a number of passages that Sister Mary Eleanor might have cited but did not. Also, the selections themselves contain material from which Whitman borrowed, though sparingly, including the section from Hegel entitled 'History as a Manifestation of Spirit,' Fichte's 'The Destination of Man,' and Herder's 'Love and Self.' I think it may reasonably be assumed that Whitman read all or most of this volume at one time or another."28 Stovall does not provide a list of the passages that he suspects had their origin in writings published in Hedge, and neither he nor Sister Mary Eleanor specifically discusses the essay by Schelling.

We do not know when Whitman first obtained a copy of Hedge or whether he might have come upon the full essay outside Hedge. The copy of Hedge that Whitman owned, the 1848 edition published by Carey and Hart, is now in the Bryn Mawr College library and contains on the verso a note written by the poet: "Have had this Vol. over twenty five years \& read it off and on many hours, days \& nights - this written Nov. 24 ' 88 in Mickle Street Camden N.J."'29 The Schelling essay would have been most useful to Whitman because in addressing the question of originality it formulates a coherent and radical aesthetic statement that provides a theoretical justification for the poetic revolution that is Leaves of Grass. Yet, in no sense can it be considered a blueprint or prescription for a particular kind of creation - no one could 
credit the notoriously changeable and abstract Schelling with providing that-but rather a theoretical exploration of the problem of artistic creation in the modern world. Whether Whitman knew this or similar essays by Shelling is in this sense irrelevant because Schelling's ideas had become so much a part of Whitman's poetic heritage that they were unavoidable.

Hazard Adams, who reprinted the essay in Critical Theory Since Plato, has observed that although "infuriatingly vague at times," Schelling "had a large influence. Much of Coleridge's Biographia Literaria is sheer Schelling, and Schelling's ideas can be detected behind those of numerous critics for a century after he had expressed them." ${ }^{30}$ Although Schelling's subjects in this essay are painting and sculpture, his analysis applies to literature as well. In The True Voice of Feeling, Herbert Read uses the essay to establish a theoretical grounding for an analysis of organic form in the poetry of Coleridge, Wordsworth, Byron and Shelley. ${ }^{31}$

In addition to its discussion of originality and organic form, On the Relation of the Plastic Arts to Nature, even in the abbreviated version published in Hedge, presents a coherent statement on such basic artistic questions as the place of the unconscious and expression of passion in art, the relation of human creativity to what Schelling identified as the unconscious creativity of nature, indirection, the participation of the particular in the universal, and the necessity for the artist to base his or her work on the spirit of the times. Since Schelling's purpose precisely was to address the problem of imitation, he does not present anything that could be used as a prescription or source. Yet Schelling provides a theoretical justification for virtually every aspect of Whitman's poetic revolution.

The artistic situation that Schelling confronts in the first decade of the century was strikingly similar to that faced by Whitman and other American literary nationalists in the 1840 s and ' 50 s. Concerned that German painters not be overwhelmed by the achievements of their Italian forebears, whose work he describes in some detail, Schelling offers a way for these artists to create without being dominated by foreign masters. He therefore counsels the creator to look beyond all predecessors and return instead to the origins of art in nature, a continuing source of inspiration. Of course, "The requirement that Art, like everything living, should commence from the first rudiment, and, to renew its youth, constantly return to them, may seem a hard doctrine to an age that has so often been assured that it has only to take from works of Art already in existence the most consummate Beauty, and 
thus at a step reach the final goal." Asking rhetorically, if we have "already the Excellent, the Perfect" why then "should we return to the rudimentary and unformed?," he responds by asserting that if the great modern artists whom the current generation seeks to copy had themselves simply imitated their predecessors, the ancients, there would be no modern art: "But such an appropriation of a Beauty not self-won, and therefore unintelligible, would not satisfy an artistic instinct that aimed throughout at the fundamental, and from which the Beautiful was again to create itself with free original energy. [The great modern painters] were not afraid, therefore, to appear simple, artless, dry, beside those exalted ancients; nor to cherish Art for a long time in the undistinguished bud, until the period of Grace had arrived" (519). Arguing against imitation of the Italian masters, Schelling insists that there is "no living transmission; no link of continuous organic growth" between the two cultures. Instead, "we must reproduce Art in the way they did, but with energy of our own, in order to be like them" (520).

Schelling identifies a situation remarkably similar to that confronting Whitman and other members of the Young America group, which was associated with the United States Magazine and Democratic Review in New York. The magazine admitted in its first number, for October 1837, that while potentially "our national literature" is "a more potent influence than any yet noticed," the truth is that "we have no national literature. We depend almost wholly on Europe, and particularly England, to think and write for us, or at least to furnish materials and models after which we shall model our own humble attempts." However tempting it might be to draw from a literature that "is immeasurably in advance of us, and is rich with ever active energies, and resources of literary habits and capital (so to speak) which mock our humble attempts at imitation," the Democratic urged American writers to resist this influence and somehow find their own way to democracy. ${ }^{32}$ Emerson in "The American Scholar" and "The Poet" argues for just such a radical break with the dominating foreign culture.

Further, since the Young Americans saw their country as occupying the vanguard of the democratic world order, Schelling's argument that the revolutionary upheaval of the times demanded nothing less than a radically new art spoke exactly to the need for a literature to advance the cause of liberal reform at home and abroad: "The new world now forming itself, as it exists in part already outwardly, in part inwardly and in the hearts of men, can no longer be measured by any standard of previous opinion; and above everything, on the contrary, loudly demands higher standards and an entire renovation" (520).

Part of this "renovation" had to do with style: the artist need no longer fear appearing "simple, artless, dry" before "exalted" predecessors. Needless to say, the Whitman literary persona, who proclaims that 
his "yawp" is "barbaric," takes up simplicity and artlessness as primary values, which he claims to have drawn from the native soil. Lest there be any mistake, the speaker of "Song of Myself" tells us in Section 20 that "I wear my hat as I please indoors or out" (47). Linking social decorum with artistic originality, Whitman in his self-review signifies his allegiance to a democratic politics and a poetry that would point the way toward a new America: "Politeness this man has none, and regulation he has none. A rude child of the people!-No imitation-No foreigner-but a growth and idiom of America." Just as the "rude" manners of the persona enable him to break with all social conventions in favor of an ostensibly original and authentic way of relating to others, so he adopts simplicity and artlessness to break with the conventions of his poetic predecessors: "First be yourself what you show in your poem - such seems to be this man's example and inferred rebuke to the schools of poets. He makes no allusions to books or writers; their spirits do not seem to have touched.him; he has not a word to say for or against them, or their theories or ways.",33

Whitman's most fundamental and courageous break with his literary predecessors comes through the verse line, and here he looks back to, and draws from, the very origins of poetry, even while fashioning an art of startling originality. Holding "in abeyance" the entire tradition of English syllabic poetry, from Chaucer on, Whitman challenges a basic expectation of what poetry should sound like. Modern and new, his verse also "invokes," as Anthony Burgess, among others, has recognized, "a tradition older than Virgil-that of Hebrew poetry. . . . There are passages of Whitman, as of Blake, which have a ring of something from the Apocrypha." ${ }^{34}$ Sculley Bradley has summarized his findings on "The Fundamental Metrical Principle of Whitman's Poetry" by noting the poet's ability to combine the Romantic principle of organic form (to be discussed below) with a recovery of much earlier metrical and structural principles. ${ }^{35}$ Whitman's rejection of English syllabic poetry is made in favor of a line that, in its use of quantity of felt stress and variable line and stanza lengths, creates its own pattern. In these ways he returns to the very origins of poetry, in Egyptian, Greek, Hebrew, and Anglo-Saxon literatures. ${ }^{36}$

Along with its return to the origins of poetry, "Song of Myself" explores virtually every conceivable dimension of origins and beginnings, of the cosmos, the nation, the individual, human consciousness, and poetic articulation. Section 44, for instance, may be read as a new creation story for the new age. The speaker returns to the moment of the creation of everything, "the huge first Nothing," to claim that "I know I was even there." As I have written elsewhere, ${ }^{37}$ Whitman accounts for the source of the cosmos, the earth and its living things, employing biological theories of evolution and recapitulation and the 
nebular hypothesis from astronomy, and in accounting for the source of the cosmos, he speaks as well of the origins of the self:

Before I was born out of my mother generations guided me, My embryo has never been torpid, nothing could overlay it.

For it the nebula cohered to an orb, The long slow strata piled to rest it on, Vast vegetables gave it sustenance,

Monstrous sauroids transported it in their mouths and deposited it with care.

All forces have been steadily employ'd to complete and delight me, Now on this spot I stand with my robust soul. (81)

With an implicit reference to Cain's murder of his brother, Whitman also revises the Biblical myth of the Fall and human evil: "Were mankind murderous or jealous upon you, my brother, my sister? / I am sorry for you, they are not murderous or jealous upon me, / All has been gentle with me, I keep no account with lamentation, / (What have I to do with lamentation?)." Instead-and in keeping with the theme of celebration which opens the poem-Whitman offers a new, joyous myth of the origins of the cosmos in which, drawing on pre-Darwinian evolutionary theory, he explicitly defines the self as a product of a process going back to the beginning of time.

In Section 31, for instance, the speaker insists upon defining himself in terms of evolutionary theory: "I find I incorporate gneiss, coal, long-threaded moss, fruits, grains, esculent roots, / And am stucco'd with quadrupeds and birds all over." Underlying the speaker's ability to return to biological origins, to "call any thing back again when I desire it," is the belief that ontogeny recapitulates phylogeny (59). After all, his "embryo has never been torpid." This is a belief that, as we will see, Schelling and other German Romantics held; that the individual work of art itself must return to the origins of the form and recapitulate its development is an application of it.

Similarly, "Song of Myself" explores the birth and growth of the American nation, recounting certain of its originating battles, such as the story of John Paul Jones's heroic victory in Section 35. Appropriately, in beginning the poem, the speaker, after an obligatory but ironic bow to the epic tradition of the bard who announces his subject matter ("I celebrate myself, and sing myself, / And what I assume you shall assume"), recounts his origins as an American, "Born here of parents born here from parents the same, and their parents the same" (29).

The poem's central subject is the origins and growth of the poet, made possible through the birth of the powers of speech. In Section 5, 
in the rapturous moment in which body and soul join together, the adult speaker returns to a moment when time itself is abolished and he rediscovers the very origins of language in sound: "Not words, not music or rhyme I want, not custom or lecture, not even the best, / Only the lull I like, the hum of your valvèd voice (33)." Through this return to a pre-verbal moment, the poet is able to recover an original and authentic speech. ${ }^{38}$ And as we have seen, in Section 2 the poet takes the reader with him to what he presents as an originating moment, both a time and place, where together they come to "possess the origin of all poems." The poet who has discovered "the origin of all poems" claims that he need not imitate the work of predecessors. In claiming that this return to origins makes possible the creation of an "original" self apart from literary tradition, he makes the paradoxical promise that reading this literary artifact will free the reader from all derivative perceptions: "You shall no longer take things at second or third hand, nor look through the eyes of the dead, nor feed on the spectres in books, / You shall not look through my eyes either, nor take things from me, / You shall listen to all sides and filter them from your self' (30).

Schelling's counsel to return to origins expresses the organicism of his thought, what Stephen Jay Gould has called the "uncompromising developmentalism" of the German Naturphilosophie, which was the "scientific incarnation of German romanticism." 39 The leading figure in this movement, Schelling pictured Nature as dynamic, progressive, and evolutionary, a force that, as we have seen, "generates and busily evolves everything out of itself" (510). Schelling suggests that the successful work of art, which he likens to an organism, contains within itself its own phylogeny: "Art, springing up out of the depths of Nature, begins with determinateness and limitation, unfolds its inward plentitude and infinity, is finally transfigured in Grace and at last attains to Soul. But we can conceive only in detail what, in the creative act of mature Art, is but one operation. No theory and no rules can give this spiritual creative power. It is the pure gift of Nature, which here, for the second time, makes a close; for, having fully actualized herself she invests the creature with her creative energy. But as, in the grand progress of Art, these different stages appeared successively, until, at the highest, all joined in one; so also, in particulars, sound culture can spring up only where it has unfolded itself regularly from the germ and root to the blossom" (519).

The notion that art must return to "germ and root" may seem paradoxical in the light of Schelling's belief in evolutionary progress. To summarize a basic philosophical assumption, he viewed nature as "moving ever from lower to higher, from initial chaos to man. . . . The history of the universe is the striving of spirit (Geist), originally unconscious, gradually and progressively to reach self-consciousness in 
man."40 But for Schelling, as Meyer Abrams has pointed out, the realization of the highest consciousness requires the recovery of an imagined original unity, through the work of "the poet-prophet who will sing the greatest of all epics, of which the theme will be the journey back to the lost paradise, or golden age, which is the restoration of a lost unity of the human intellect with itself and with nature. This is very like the prophetic role that Wordsworth had assumed in his Prospectus and Prelude, and it approximates the 'high argument' of the more-thanheroic poem that, as a chosen son who has been granted this 'vision,' he felt it was his destined office to compose. Schelling's judgment that the time was not entirely ripe for such a poem may reflect a circumstance that he had himself begun a nature epic, but then had given it up. And Wordsworth . . . was far from alone in assuming the persona of a bard who present, past, and future sees, and who undertakes the theme of mankind's journey back toward his spiritual home, which will be at once a paradise and a golden age of peace after conflict, and of integration after severance." 41 Whitman affirmed this assumption, that nature reaches its high point in human consciousness, in the speaker's statement in Section 44 that he is "an acme of things accomplish'd, and I am encloser of things to be." For both writers, implicit in that articulation is an awareness of origins, of the "original energy" still at work in the creation. "Song of Myself," then, takes its place within a Romantic tradition of return, recovery and reintegration, but as a belated American vision-and as the creation of a "large" maker who claimed to "contain multitudes"-it characteristically seeks to outdo its predecessors.

Schelling, as Gould has summarized his philosophy, believed in "the unity of nature and its laws. Man is the highest configuration of matter on earth, but we are indissolubly linked to all objects as the goal toward which they strive. Nature and spirit, the organic and inorganic, are one; the universe itself is a single organism." 42 This, of course, is an underlying assumption of "Song of Myself," where the most important symbol of the unity of the human and nature is the grass, which in Section 6 Whitman connects both to the self- "I guess it must be the flag of my disposition, out of hopeful green stuff woven"-and something larger: "Or I guess it is the handkerchief of the Lord, / A scented gift and remembrancer designedly dropt, / Bearing the owner's name someway in the corners, that we may see and remark, and say Whose?" (33). The grass symbolizes at once humankind's physical origins and our return to the earth, the source of new growth, as in the poet's leave-taking: "I bequeath myself to the dirt to grow from the grass I love, / If you want me again look for me under your boot-soles" (89).

Even as Schelling looked back to human origins, he described the universe as having "no determinate dimension, neither length, breadth 
nor depth, since it has all in equal infinity: or that the Art of creative Nature is formless, because she herself is subjected to no form." Consequently, he called for literary structures that are similarly open-ended, in which form is determined by the artistic material. The artist's goal is to find "That lofty Beauty in which the fulness of form causes Form itself to disappear (514)." The material of the work of art contains its own form, to be discovered within and not imposed from without: the highest beauty is "characterless, but it is so as we say of the universe." Artistic form grows naturally from its material: "Form would indeed be a limitation to the Essence if it existed independent of it. But if it exists with and by means of the Essence, how could this feel itself limited by that which it has itself created? Violence would indeed be done by a form forced upon it, but never by one proceeding from itself' (513). Coleridge in Biographia Literaria and elsewhere developed this idea, as did Emerson, who in "The Poet" gave it its classic American expression, insisting that "it is not metres, but a metre-making argument that makes a poem $-\mathrm{a}$ thought so passionate and alive that like the spirit of a plant or an animal it has an architecture of its own, and adorns nature with a new thing." 43

On the Relation of the Plastic Arts to Nature connects the concept of organic form with another idea of central importance to Whitman: the function of art as linking realms thought to be separate. Schelling wrote that art is "the vital connecting link" between the "Limited" human being and the essence of the "Unlimited" (511). In discussing the philosophical principles behind Coleridge's exposition of the idea of organic form, Herbert Read has identified Schelling's essay as perhaps the most important Romantic formulation of art as the vehicle which links the finite human with eternal nature: "universals and particulars, natura naturans and natura naturata. The point at issue is not the recognition or differentiation of these two aspects of reality, but the possibility of mediating between them. . . . Art is the active bond between the soul and nature, between essence and existence." 44 As the philosopher Emil Fackenheim has summarized the underlying thesis of Schelling's aesthetic, "the identity of finite and Infinite, striven for everywhere, becomes actual in art." 45

Whitman's poetry combines these two related principles, of art as an act of linking and of form as a natural outgrowth of its subject. His verse line, as we saw, embodies this organic principle, as he asserted in the 1855 preface in explaining his decision to go beyond the regularity of rhyme: "The profit of rhyme is that it drops seeds of a sweeter and more luxuriant rhyme, and of uniformity that it conveys itself into its own roots in the ground out of sight. The rhyme and uniformity of perfect poems show the free growth of metrical laws and bud from them as unerringly and loosely as lilacs or roses on a bush, and take shapes as 
compact as the shapes of chestnuts and oranges and melons and pears, and shed the perfume impalpable to form" (716). In "Song of Myself" he proceeds, immediately after affirming the self, "I celebrate myself," to link speaker and reader in a network of common assumptions: "And what I assume you shall assume, / For every atom belonging to me as good belongs to you" (28). As is the case in Schelling's identity philosophy, art unites entities that are thought to be separate. Making use of another principle central to Schelling, polarity, Whitman's art is a "vital efficient link" enabling both reader and speaker to understand the connections between virtually every conceivable opposition: body and soul, life and death, city and country, past and present, and, as he writes in Section 16, "old and young ... foolish as much as the wise ... A Southerner soon as a Northerner" (44). In Section 21, as the "poet of the Body and . . . the poet of the Soul," he connects other oppositions, including "the pleasures of heaven ... and the pains of hell" (48). Throughout the poem he brings together such opposites as virtue and vice, presence and absence, the material and immaterial, consciousness and unconsciousness, and the male and the female. As is the case with "Crossing Brooklyn Ferry," "Out of the Cradle Endlessly Rocking," and other works, "Song of Myself" unfolds organically through its exploration of the multiple connections or links by which human experience takes on meaning in the world. In beginning his poetic career, Whitman, as he wrote in an early note, thought of both individual poems and his projected life's work as constituting a single organic structure, as possessing a "unity, in the same sense that the earth is, or that the human body, (senses, soul, head, trunk, feet, blood, viscera, man-root, eyes, hair) or that a perfect musical composition is." And he saw his poetry as connecting opposing elements: "Great constituent elements of my poetry-Two, viz: Materialism-SpiritualityThe Intellect is what is to be the medium of these and to beautify and make serviceable there." 46

Schelling also prefigures another central principle in Whitman's aesthetic, indirection. Asserting that the essence of nature is not its temporary and transient physical manifestation, but the underlying movement or energy that impels its constant unfolding, he warns the artist against attempting to achieve merely a faithful reproduction of what is: "But should he attempt consciously to subordinate himself altogether to the Actual, and give back with servile fidelity the already existing, he would produce larvae but no works of Art." Instead, the successful artist "withdraw[s] himself from the product, from the creature; but only to raise himself to the creative energy, and spiritually to seize this. . . . He forsakes the creature to regain it with thousand-fold interest, and in this sense certainly to return to Nature." As Emil Fackenheim has summarized Schelling's position, "Art finally is not the 
imitation of nature, but the representation of an infinite Idea in a finite product. The artist does not imitate nature: he transfigures it. Nature is the finite with a nisus toward infinity; art is the synthesis of finiteness and infinity. Nature is a mere allegory of the Absolute; art, its symbolic representation." 47

In the 1855 preface Whitman explicitly separates himself from the concept of art as a direct representation, developing instead the concept of indirection, which he links to his democratic vision: "the expression of the American poet is to be transcendent and new. It is to be indirect and not direct or descriptive or epic. Its quality goes through these to much more." The notion of indirection is especially appropriate for the use of a democratic subject matter; art avoids a faithful rehearsal of the traditional subjects of "age and wars." In "the republic" the "theme is creative and has vista. Here comes one among the wellbeloved stonecutters and plans with decision and science and sees the solid and beautiful forms of the future where there are now no solid forms" (714). Later in the preface Whitman directly asserts that "The indirect is always as great and real as the direct. The spirit receives from the body just as much as it gives to the body" (726).

Just as Schelling defines the goal of the artist as to express "the ever-creative original energy of the world," so Whitman, in giving expression to the "original energy" of Nature, accepts a basic premise of Schelling's aesthetic: that nature contains an inherent creativity and intelligence that, although unconscious, is analogous to human creativity. Schelling observes that "The science by which Nature works is not, indeed, like human science, connected with reflection upon itself: in it, the conception is not separate from the act, nor the design from the execution. Thus, rude matter strives, as it were, blindly after regular shape, and unknowingly assumes pure stereometric forms, which belong nevertheless to the realm of ideas, and are something spiritual in the material." Art reveals "to us, as in outline, this unadulterated energy of creation and activity in Nature" (512).

Schelling's highly suggestive description of the activity of unconscious nature carries an immediate resonance for the reader of Whitman's poetry:

The sublimest arithmetic and geometry are innate in the stars, and unconsciously displayed by them in their motions. More distinctly, but still beyond their grasp, the living cognition appears in animals; and thus we see them, though wandering about without reflection, bring about innumerable results far more excellent than themselves:-the bird that, intoxicated with music, transcends itself in soul-like tones; the little artistic creature, that, without practice or instruction, accomplishes light works of architecture; - but all directed by an overpowering spirit, that lightens in them already with single flashes of knowledge, but as yet appears nowhere as the full sun, as in Man. 
One thinks of both Whitman's brilliant treatment of astronomy and his sublime hymn in Section 32 to the "placid and self-contain'd" animals, which "show their relations to me and I accept them, / They bring me tokens of myself, they evince them plainly in their possession." Interpreting their purposeful intelligence, the speaker "wonder[s] where they get those tokens, / Did I pass that way huge times ago and negligently drop them?" (60). Whitman again summons up the concept of origins, imagining a prehistoric time when the human had communicated a self or presence, now lost, to the animal, a perception that the animal now returns to the human. Whitman's poetry becomes an "efficient link" between the animal and human realms; what Schelling called "this living cognition in animals" finds sublime expression.

In his self-review in the Brooklyn Daily Times, Whitman, who claimed that his poetry contained the "unconscious teaching of the fine brute," makes explicit his understanding of the importance of the unconscious in the artist. Similarly Schelling asserts that in "Art, not everything is performed with consciousness; that, with the conscious activity, an unconscious action must combine; and that it is of the perfect unity and mutual interpenetration of the two that the highest in Art is born" (512). Further, "this seal of this unconscious science" is essential if art is to possess that "unfathomable reality wherein it resembles a work of Nature" (512). Implicitly, then, for Schelling an additional means for the artist to return to origins is to harness the power of the unconscious, the source of "original intuition." Needless to say, the poet of "The Sleepers" and "Out of the Cradle Endlessly Rocking" found a way to draw from the unconscious, as he does in Section 50 of "Song of Myself," in which the poet attempts to discover and articulate a meaning which lies beyond consciousness and even speech, one which becomes available only in sleep:

There is that in me-I do not know what it is-but I know it is in me.

Wrench'd and sweaty-calm and cool then my body becomes, I sleep-I sleep long.

I do not know it-it is without name-it is a word unsaid, It is not in any dictionary, utterance, symbol.

Something it swings on more than the earth I swing on, To it the creation is the friend whose embracing awakes me.

Perhaps I might tell more. Outlines! I plead for my brothers and sisters.

Do you see $\mathrm{O}$ my brothers and sisters? 
It is not chaos or death-it is form, union, plan-it is eternal life-it is Happiness.

(88)

The poet links a dimension of his unconscious with a mysterious movement within "the creation," one which awakens him to the deepest dimensions of being. The origins of art, both Schelling and Whitman recognize, are to be found both in the external world and in the unconscious self, through which the individual is able to return to the origins of thought. The artist who articulates "as in outline, this unadulterated energy of creation and activity in Nature," Schelling wrote, is "to be called happy" (512).

Schelling balanced his discussion of the artist's personal vision by exploring the essential connection between art and the public realm: "For Art is especially dependent upon the tone of the public mind as the more delicate plants on atmosphere and weather: it needs a general enthusiasm for Sublimity and Beauty, like that which, in the time of the Medici, as a warm breath of spring, called forth at once and together all those great spirits. . . . It is only when public life is actuated by the same forces through whose energy Art is elevated, that the latter can derive an advantage from it" (520). Similarly, in the 1855 preface Whitman wrote that "The direct trial of him who would be the greatest poet is today" (728). As we are increasingly realizing, Leaves of Grass is not an escape into the realm of visionary poetry from the social and political conflict that Whitman faced as a newspaper editorialist, but an engagement of those issues from a new perspective. ${ }^{48}$ His poetry implicitly confronts such political subjects as the displacement of the workingman by the new industrial order and particularly the threat of dismemberment of the Union posed by the adherence of the South to slavery, the speaker identifying in Section 33 with "the hounded slave, I wince at the bite of the dogs" (66).

Whitman saw his poetry, then, as a vehicle to involve the reader in a process of creating a new America, even as the nation renewed itself through a continuous process of rediscovering its revolutionary origins. ${ }^{49}$ As he wrote in the 1855 preface, "The American poets are to enclose old and new for America is the race of races" (713). As we have seen, Schelling looks to art to play a leading role in an age of radical change and renovation: "To different ages are given different inspirations. Can we expect none from this age, since the new world now forming itself, as it exists in part outwardly, in part inwardly and in the hearts of men, can no longer be measured by any standard of previous opinion; and above everything, on the contrary, loudly demands higher standards and an entire renovation?" (520)

In On the Relation of the Plastic Arts to Nature Schelling was remarkably successful in stating ideas that would continue to help shape 
Romanticism. And yet, in keeping with his theme of defining the conditions of an original art, he explicitly leaves space for the artistic practitioner: "Art and Science can move only on their own axes; the artist, like every spiritual laborer, can only follow the law that God and Nature have written in his heart. None can help him-he must help himself; nor can he be outwardly rewarded, since anything he would produce for the sake of aught out of itself, would thereby become a nullity." Similarly, in preparing to take leave of the reader in Section 46 , Whitman seems to echo Schelling in writing that "Not I, not anyone else can travel that road for you, / You must travel it for yourself" (83). The purpose of the best "teaching" is stimulative, not prescriptive:

I am the teacher of athletes,

He that by me spreads a wider breast than my own proves the width of my own,

He most honors my style who learns under it to destroy the teacher. (84)

We might well ask if to present the issues in this way is not at the same time to confront the reader and succeeding poets with the problem of entangling influence. As a self-annointed teacher, Whitman challenges his successors to enter into a competitive game on his terms. Paradoxically, the poet who in Section 2 promises the reader that "You shall no longer take things at second or third hand . . . nor look through my eyes either, nor take things from me, / You shall listen to all sides and filter them from yourself," becomes himself a verbal presence with which both reader and succeeding poets are challenged to come to terms.

Schelling, who, as Fackenheim wrote, "distinguishes between a theory of art and a philosophy of art," in no sense considered himself to be a practical critic or a prescriptive aesthetician, but a theorist, and perhaps for that reason his ideas have proved so influential. ${ }^{50}$ As Hazard Adams noted, "he had a large influence. Much of Coleridge's Biographia Literaria is sheer Schelling, and Schelling's ideas can be detected behind those of numerous critics for a century after he expressed them." ${ }^{51}$ In any event, Schelling presents not a single pattern, but a set of opposites that somehow must be reconciled: along with a confrontation with the times, the artist is to return to origins; art somehow harmonizes conscious intention with unconscious depth; through organic structures, the artist achieves a form that overcomes all form; the artist, fully conscious of the history of the medium, is still able to put his knowledge aside in returning to origins; while encouraged to give full expression to his or her passional life, the artist is to use art as a device to establish connections with external reality. "Song of Myself" is responsive to just such complex and productive oppositions. 
To realize the extent to which "Song of Myself" embodies the aesthetic principles of $O n$ the Relation of the Plastic Arts to Nature is to see this most American of poets as a belated exponent of a central theme within Romanticism. ${ }^{52}$ The drama of origins, of the poet's return to the moment of the "huge first Nothing," also functions as a metaphor for the mind's discovery of its imaginative depths. It serves as a strategy available to the artist anxious to escape the "creeds and schools" of tradition, even of his own Romantic forerunners. Whitman explores this theme with a scope and depth made possible in part by the astounding discoveries of the astronomers, biologists, and geologists. The poet's vision of the future, of a world where, as he writes in Section 45, "There is no stoppage and never can be stoppage," is based on a return to origins: "If I, you, and the worlds, and all beneath or upon their surfaces, were this moment reduced back to a pallid float, it would not avail in the long run, / We should surely bring up again where we now stand, / And surely go as much farther, and then farther and farther" (82). The search for origins of self, Whitman demonstrates, is inseparable from the great search for the origins of the cosmos.

But as Whitman well understood, such a cosmic vision, no matter how dazzling, cannot relieve the poet of the burden of self-consciousness which comes from the awareness that the return to origins is itself a strategy meant to help the poet hold "in abeyance" the very "creeds and schools" of tradition that threaten to swallow him up. Whitman's speaker defines himself almost from the beginning, as in Section 4, as a self-aware subject, one who is "Both in and out of the game and watching and wondering at it" (32). That is to say, in the terms of Schiller's "On Naive and Sentimental Poetry," an essay Hedge also included in Prose Writers of Germany, that he understood that the time of the "naive poet," such as that of the early Greeks, the poets who could unselfconsciously portray nature, had long since passed. The modern poet is "sentimental," aware of his or her inevitable distance not only from nature itself but especially from the naive poets who portrayed their oneness with it. As Schiller wrote, the naive poet "seems to make no distinction in his love for the object, between that which is in itself, and that which is through art and human will. Nature seems to interest his intellect and curiosity more than his moral sense: he does not cling to her, as we do, with heartiness, with sensibility, with a sweet sadness. And even when he personifies and deifies her single manifestations, and represents their effects as actions of a free being, he abolishes in her that tranquil necessity, by which precisely she is so attractive to us. Nothing satisfies him but the free and living, nothing but characters, actions, fates and manners. And while we, in certain moral moods of mind, could wish to give up the superiority of our free volition, which causes us so much strife with ourselves, so much unrest and confusion, for the 
choiceless but tranquil necessity of the irrational, the Greek fancy, precisely the reverse, is busy making human nature inchoate even within the inanimate world, and giving influence to Will in the province of blind necessity." On the other hand, the self-aware modern poet, such as Whitman, is sentimental because conscious of his inevitable separation from nature: "He reflects upon the impression which objects make upon him, and the emotion into which he throws us and is thrown himself, is only based upon that reflection. . . . Hence the sentimental poet is always involved with two conflicting representations and perceptions, with reality as a limit and with his idea as the unlimited: and the mingled feeling which he excites will always betray his two-fold source." 53

Aware of the gap between poetic vision and action in the world, between the ideal republic and the actual America, between the poet as "divine literatus" and his marginal status, Whitman expresses the "unrest and confusion" to which the modern poet inevitably is heir. $\mathrm{He}$ seeks with the reader to escape "the spectres of books," but in the end adds another to the long list of books to be escaped from, even as his book draws from others. Whitman's attempt to articulate a return to origins, to claim that he was present even at "the huge first Nothing," was compelled in part, we can see, by a sense of disconnection from the past in an age of rapid change and underlying social, economic, and national dislocation.

Where, as in "Passage to India" (1871), Whitman does not confront those complexities, where the return is more willed than earned, we recognize a hollowness in the poet's own return to this theme. Here the geographic "circumnavigation of the world" made possible by the opening of the Suez Canal and the completion of the transcontinental railroad is intended to serve as a vehicle for a "Passage indeed $\mathrm{O}$ soul to primal thought . . . to realms of budding bibles," which becomes the "mind's return, / To reason's early paradise, / Back, back to wisdom's birth, to innocent intuitions, / Again with fair creation" (418). It is almost as if Whitman seeks to will a return, to use Schiller's terms, to the situation of the innocent or naive poet-with none of the selfconsciousness of the sentimental poet. But in "Song of Myself," Whitman engages history. Far from denying the "creeds and schools" of literary tradition, Whitman draws from them in a new, more complex way than his immediate predecessors, finding a "foreground" even longer than that envisioned by Emerson, whose work he "honors" by "learn[ing] under it to destroy the teacher." In asserting that "He that by me spreads a wider breast than my own proves the width of my own, / He most honors my style who learns under it to destroy the teacher," Whitman implicitly invites the reader to identify the poet's own teachers and compare his work with theirs. In one sense, then, Whitman "de- 
stroys" such predecessors and teachers as Carlyle, Coleridge, Schelling, and Emerson through his ability to spread "a wider breast" than theirs. In that very act we see another paradox of originality, the poet's redefinition and continuation of the very literary traditions from which he claims to have escaped.

Such a return to origins, then, is not an escape from literary history, but a means of confronting it and one's predecessors so as to define a relationship to both in a new and more complex way. Whitman's radical break with literary practice reflects both a perception of historical discontinuity and the imperative need to redefine humankind's relationship to the deepest past. Out of that awareness comes the complex consciousness at once of historical discontinuity and of the need to reestablish a connection with the past, of the gap between vision and action, and the need both to embrace and resist the sprawling American democracy.

In undertaking the ancient poetic task of exploring cosmic origins and destiny, a task made more urgent by America's movement towards fratricidal war and economic dislocation, Whitman, paradoxically, found a powerful, new and "original" voice. The aesthetic philosophy of Schelling's On the Relation of the Plastic Arts to Nature proved useful precisely because it provided the artist with a perspective from which to confront his actual situation, both political and literary. To understand the return to origins in Whitman's poetry is to gain an appreciation not only for the magnitude of his achievement, but also for the urgency of a time that demanded, in Schelling's words, "an entire renovation."

\section{College of William \& Mary}

\section{NOTES}

1 Leaves of Grass, Comprehensive Reader's Edition, ed. Sculley Bradley and Harold W. Blodgett (New York: New York University Press, 1965), 30. Additional quotations from Leaves of Grass and the 1855 preface will be from this edition.

2 Brooklyn Daily Times, September 29, 1855. Reprinted in Leaves of Grass: A Norton Critical Edition (New York: Norton, 1973), 777.

3 North American Review 82 (January 1856), 275. Reprinted in Norton Critical Edition, 779-780.

4 The Collected Works of Ralph Waldo Emerson, ed. Alfred R. Ferguson, Joseph Slater, et al., 4 vols. to date (Cambridge: Harvard University Press 1971- ); vol. 2, Essays: First Series (1979), ed. Slater, 47.

5 Thomas McFarland, Originality and Imagination (Baltimore: Johns Hopkins University Press, 1985), 14-15. From a lecture on "Chaucer."

6 Edward Waldo Emerson, ed., The Complete Works of Ralph Waldo Emerson, Centenary Edition, 12 vols. (Boston: Houghton Mifflin, 1903-1904), 8:160. 
7 In Frederick Henry Hedge, Prose Writers of Germany (Philadelphia: Carey and Hart, 1848), 519-520. Additional references will be identified in the text.

8 Norton Critical Edition, 731-732.

9 Leslie Brisman, Romantic Origins (Ithaca: Cornell University Press, 1978), 21-22.

10 The Myth of Eternal Return, trans. Willard Trask (New York: Pantheon, 1954), 153.

11 Robert Richardson, Jr., Myth and the American Renaissance (Middletown, CT: Wesleyan University Press, 1978).

12 F. O. Matthiessen, The American Renaissance (New York: Oxford University Press, 1941). For discussion of Emerson's response to the emerging capitalist order, see Carolyn Porter, Seeing and Being (Middletown: Wesleyan University Press, 1981).

13 Collected Works, 3:6-7.

14 The Anxiety of Influence (New York: Oxford University Press, 1973).

15 Collected Works, 1:7.

16 Collected Works, 2:36, 37.

17 The Writings of Henry David Thoreau, ed. William L. Howarth, et al., 11 vols. to date (Princeton: Princeton University Press, 1971- ); Vol. 1, Walden: or Life in the Woods, ed. J. Lyndon Shanley (1971), 306.

18 Edgar Allan Poe, Poetry and Tales (New York: The Library of America, 1984).

19 Leon Chai, The Romantic Foundations of the American Renaissance (Ithaca: Cornell University Press, 1987), 131-132.

20 Terry Eagleton, The Ideology of the Aesthetic (Oxford and Cambridge, MA: Basil Blackwell, 1990), 133.

21 Originality and Imagination, 23-24.

22 Whitman's review appeared in the Eagle on December 4, 1847, and has been reprinted in The Gathering of the Forces, 2 vols., ed. Cleveland Rogers and John Black (New York: Putnam, 1920), 2:298-299. Significantly, Whitman praised Coleridge, who "stands above all poets," for being "passionate without being morbid-he was like Adam in Paradise, and almost as free from artificiality."

23 American Renaissance, 7.

24 Literary Transcendentalism: Style and Vision in the American Renaissance (Ithaca: Cornell University Press, 1973), 142.

25 North American Review 67 (Oct. 1848), 485.

26 Distributor of the final number of the Dial in England, Chapman sought to create a publishing firm that would both publish radical English writers and introduce advanced thinkers, both American and German, into England. See Gordon S. Haight, George Eliot and Fohn Chapman (New Haven: Yale University Press, 1940), 6-14.

27 Sister Mary Eleanor, SHCJ, "Hedge's Prose Writers of Germany as a Source of Whitman's Knowledge of German Philosophy," Modern Language Notes 61 (June 1946), 388.

28 Floyd Stovall, The Foreground of "Leaves of Grass" (Charlottesville: University Press of Virginia, 1974), 195. 
29 From Peter Van Egmond, "Bryn Mawr College Library Holdings of Whitman Books," Walt Whitman Review 20 (June 1974), 45.

30 Hazard Adams, ed., Critical Theory since Plato (New York: Harcourt Brace Jovanovich, 1974), 444-445.

31 Herbert Read, The True Voice of Feeling (New York: Pantheon Books, 1953), 16.

32 Democratic Review 1 (Oct. 1837), 14. For an analysis of the extensive treatment of Continental Romantic literature in the magazine, see Joshua D. Scholnick, "Democrats Abroad: Continental Literature and the American Bard in the United States Magazine and Democratic Review," American Periodicals 3 (1993), 75-99.

33 Norton Critical Edition, 777-778.

34 Anthony Burgess, "The Answerer," in Urgent Copy (New York: W. W. Norton, 1968), 48-53; rpt. Norton Critical Edition, 973.

35 Sculley Bradley, "The Fundamental Metrical Principle in Whitman's Poetry," American Literature (1939); rpt. On Whitman: The Best from "American Literature" (Durham: Duke University Press, 1987), 70.

36 The classic discussion of Whitman's use of Biblical sources is Gay Wilson Allen, "Biblical Analogues for Walt Whitman's Prosody," Revue Anglo-Americaine 10 (1953), 490-507. For Whitman's use of Egyptian sources, see Stephen J. Tapscott, "Leaves of Myself: Whitman's Egypt in 'Song of Myself,' "American Literature 50 (1978), 49-73; rpt. On Whitman, 202-227.

37 “" 'The Password Primeval': Whitman's Use of Science in 'Song of Myself,' " Studies in the American Renaissance, ed. Joel Myerson (Charlottesville: University Press of Virginia, 1986), 385-425.

38 In “ 'This Irrepressible Yearning': Whitman's Poetics of Love," in American Declarations of Love, ed. Ann Massa (London: Macmillan, 1990), 46-67, I discuss this passage from the perspective of Lacan's linguistic theory.

39 Stephen Jay Gould, Ontogeny and Phylogeny (Cambridge: Belknap Press of Harvard University Press, 1977), 35, 36.

40 Gould, 36.

41 Meyer Abrams, Natural Supernaturalism (New York: Norton, 1971), 224-225.

42 Gould, 36.

43 The Collected Works, 3:6.

44 Read, 16.

45 Emil Fackenheim, Philosophical Quarterly 4 (1954), 325.

46 Norton Critical Edition, 763. From Notes and Fragments, ed. R. M. Bucke (Folcroft, PA: Folcroft Press, 1899), Part II, item 1, 55.

47 Fackenheim, 316.

48 See Betsy Erkkila, Whitman the Political Poet (New York: Oxford University Press, 1989).

49 See Kerry C. Larson, Whitman's Drama of Consensus (Chicago: University of Chicago Press, 1988). 
50 Fackenheim, 310.

51 Adams, 445.

52 For a thorough discussion of this complex subject, especially in the work of Poe, Emerson, Hawthorne and Melville, see Chai's The Romantic Foundations of the American Renaissance.

53 "Upon Naive and Sentimental Poetry," in Frederick H. Hedge, ed., The Prose Writers of Germany (Philadelphia: Carey and Hart, 1847), 378, 382. The translator was Rev. J. Weiss. 